\title{
Avalonian proximity of the Ordovician Miramichi Terrane, northern New Brunswick, northern Appalachians: paleomagnetic evidence for rifting and back-arc basin formation at the southern margin of Iapetus
}

\author{
Margo J. Liss, Ben A. van der Pluijm * and Rob Van der Voo \\ Department of Geological Sciences, University of Michigan, 1006 C.C. Little Building, Ann Arbor, MI 48109-1063, USA
}

(Received December 15, 1992; revised version accepted June 1, 1993)

\begin{abstract}
A paleomagnetic investigation of the Middle Ordovician Tetagouche Group in northern New Brunswick was undertaken to determine the paleogeographic position of the Miramichi Terrane. Stepwise thermal demagnetization of pillow basalts reveals a high-temperature characteristic magnetization with a mean direction of $D=060^{\circ}, I=+69^{\circ}, k=22, \alpha_{95}=13^{\circ}$ (tilt-corrected, $N=7$ sites; 73 samples). A positive fold test and the presence of antipodal normal and reversed polarity directions indicate that this ancient direction is Ordovician in age, with a paleopole position of $52^{\circ} \mathrm{N}, 352^{\circ} \mathrm{E}$. The corresponding paleolatitude of $53^{\circ} \mathrm{S}$ places these volcanic rocks near the southern margin of the Iapetus Ocean, at paleolatitudes similar to those revealed by Avalon for the Middle to Late Ordovician. The mafic and felsic volcanic rocks and marine sedimentary rocks of the Tetagouche and Fournier groups have been interpreted to be remnants of a rifted continental margin and a Middle Ordovician back-arc basin. Our results show that the process of rifting and back-arc basin formation occurred at the Avalonian margin of Iapetus, which implies that Ordovician subduction was not restricted to the Laurentian margin, but also marks the southern margin of lapetus.
\end{abstract}

\section{Introduction}

The interpretation of tectono-stratigraphic zones (terranes) and tectonic scenarios in the Canadian segment of the northern Appalachians have changed significantly over the years as more geologic information has become available (e.g., Williams, 1964, 1979; Rast et al., 1976; Ruitenberg et al., 1977; Williams and Hatcher, 1983; Fyffe and Fricker, 1987; van der Pluijm and van Staal, 1988; Williams et al., 1988; Stockmal et al., 1990). In particular, the nature and extent of the boundaries of these tectono-stratigraphic zones, which were defined on the basis of lithologic,

* Corresponding author. geochemical and structural differences in bedrock geology, have been modified with each new interpretation. Deep seismic reflection studies (e.g., Marillier et al., 1989) indicate a decoupling of the surface geology and the deeper crust and characterize three main crustal blocks: Grenville, Central and Avalon. Moreover, using $\mathrm{Pb}$-isotopic differences in plutonic rocks, Ayuso and Bevier (1991) divided the northern Appalachians into four distinct lower crustal blocks: the Humber, Central, Avalonian and Meguma terranes.

In spite of some differences of opinion, it is becoming increasingly clear that three main areas can be distinguished in the northern Appalachians: two continental blocks (Laurentia and Avalon) and a complex area in between. A recent northern Appalachian zonal subdivision emphasizes the complexity of the geology (Fig. 1, van 
der Pluijm and van Staal, 1988) and distinguishes three zones: (1) the Humber zone, which represents the North American (Laurentian) margin during the Early Paleozuic; (2) the Central Mobile Belt, a combination of Williams' (1979) Dunnage and Gander tectonostratigraphic zoncs, composed of a variety of tectonic elements representing remnants of Iapetus; and (3) the Avalon zone, a microcontinent that was associated with Gondwana, at least in the Early Paleozoic (Van der Voo, 1988).

In the Early Ordovician, the margin of Laurentia was oriented roughly east-west at $10^{\circ}-20^{\circ} \mathrm{S}$ latitude, while Avalon's margin was located at approximately $50^{\circ} \mathrm{S}$ (Van der Voo, 1988, 1989, 1990). The location of a small marginal basin proximal to Laurentia (i.e. at the northern edge of Iapetus) has been recognized through paleomagnetic investigations of the Moreton's Harbour Group in Newfoundland (van der Pluijm et al.,
1990; Johnson et al., 1991). These studies further suggested that Ordovician closure of this basin by collision of the arc with Laurentia is recorded by the Taconic orogenic pulse in Newfoundland. Paleomagnetic studies of other units in the Central Mobile Belt have identified terranes that were also located near Laurentia (e.g., Wellensiek et al., 1990) or in the central portion of Iapetus (Van der Voo et al., 1991).

New Brunswick is located between the North American part of Laurentia and the Avalonian microplate (Fig. 1). The Lower Paleozoic units of the province are composed of obducted oceanic crust and other terranes that formed within the Iapetus basin (Williams, 1979; van Staal, 1987; van der Pluijm and van Staal, 1988). Commonly, New Brunswick has been compared to Newfoundland in terms of tectono-stratigraphic subdivisions and tectonic scenarios (e.g., Rast et al., 1976; Fyffe, 1977; Ruitenberg et al., 1977;

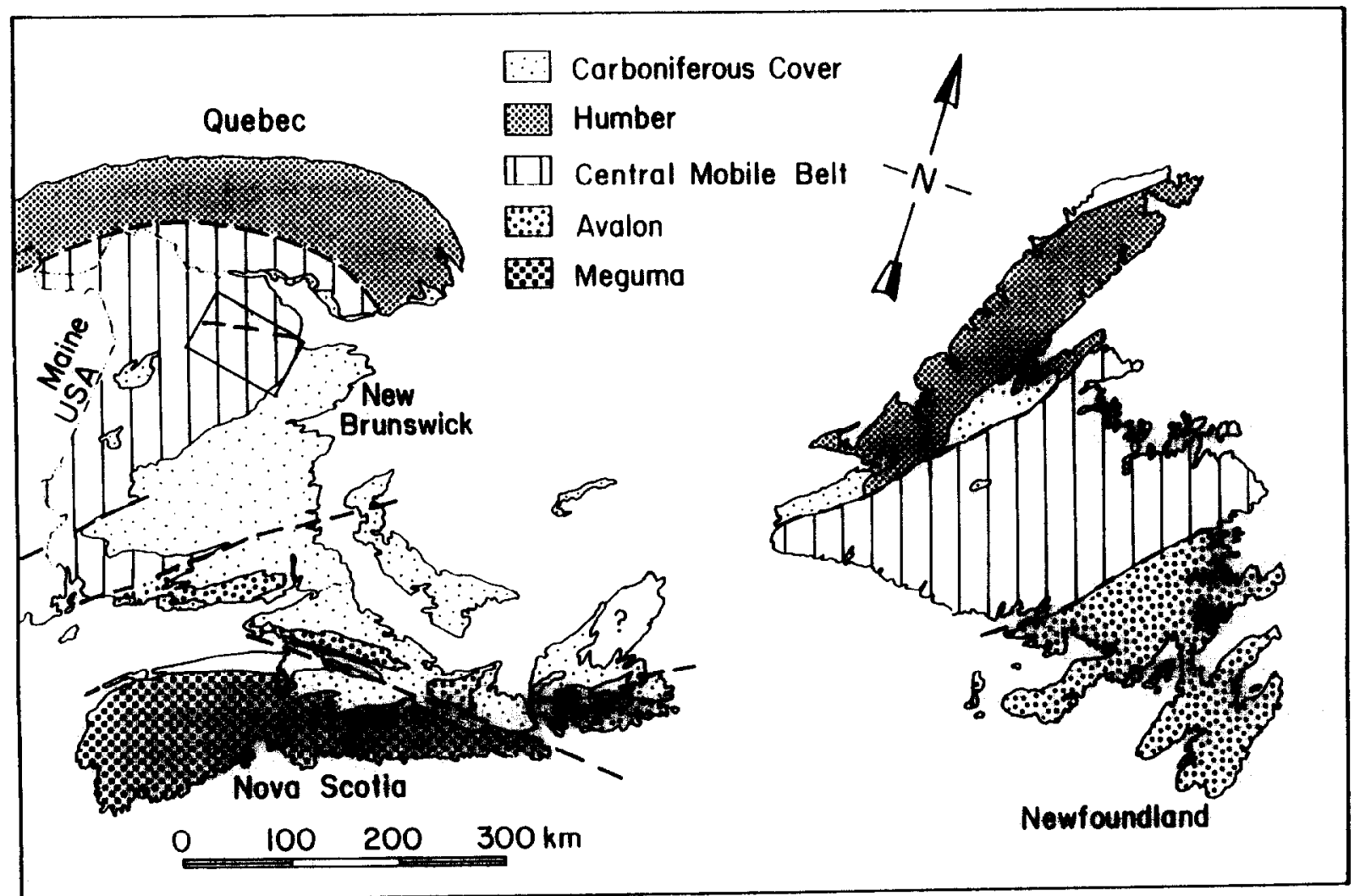

Fig. 1. Subdivision of the Canadian Appalachians. Humber represents the margin of cratonic North America (Laurentia); the Central Mobile Belt consists of elements of Iapetus; Avalon is a microcontinent associated with northwestern Gondwana. Rectangle in New Brunswick denotes the study area. 
Williams and Hatcher, 1983; Fyffe and Fricker, 1987; van der Pluijm and van Staal, 1988), but lithologic, structural and geochronologic complexities hamper some of these correlations. Paleogeographic reconstructions provide an alternative method to examine relationships along the northern Appalachian belt. Paleomagnetic study in particular provides an opportunity to determine the paleogeography of terranes such as the Miramichi in New Brunswick and to test the myriad of tectonic models for the northern Appalachians.

\section{Geologic setting}

The oldest exposed group of rocks in northern New Brunswick, the Miramichi Group, consists of quartzites, quartz wackes and phyllites that were deposited as turbidites (Rast and Stringer, 1974; Skinner, 1974; Ruitenberg et al., 1977; van Staal,
1987). Until recently, the Miramichi Group was considered to be part of the lower Tetagouche Group (Skinner, 1974; Fyffe, 1987; van Staal, 1987), but it is now considered to be separate from, but in stratigraphic contact with, the overlying Tetagouche Group (van Staal et al., 1990; van Staal and Fyffe, 1991). David et al. (1991) correlate mafic dikes within the Miramichi Group in southwestern New Brunswick with mafic volcanic rocks of the Tetagouche Group that constrain the age of the Miramichi sediments as pre-Middle Ordovician, which is supported by fossil evidence (e.g., Fyffe et al., 1983; Neuman, 1984; Fyffe and Fricker, 1987). Collectively, these pre-Upper Ordovician units form the Miramichi Terrane.

Northern New Brunswick's Middle Ordovician volcanic rocks are divided into two groups separated by a Late Ordovician/Silurian blueschist belt inferred to represent a suture (Fig. 2; van Staal et al., 1990). The Tetagouche Group (Fig. 2)

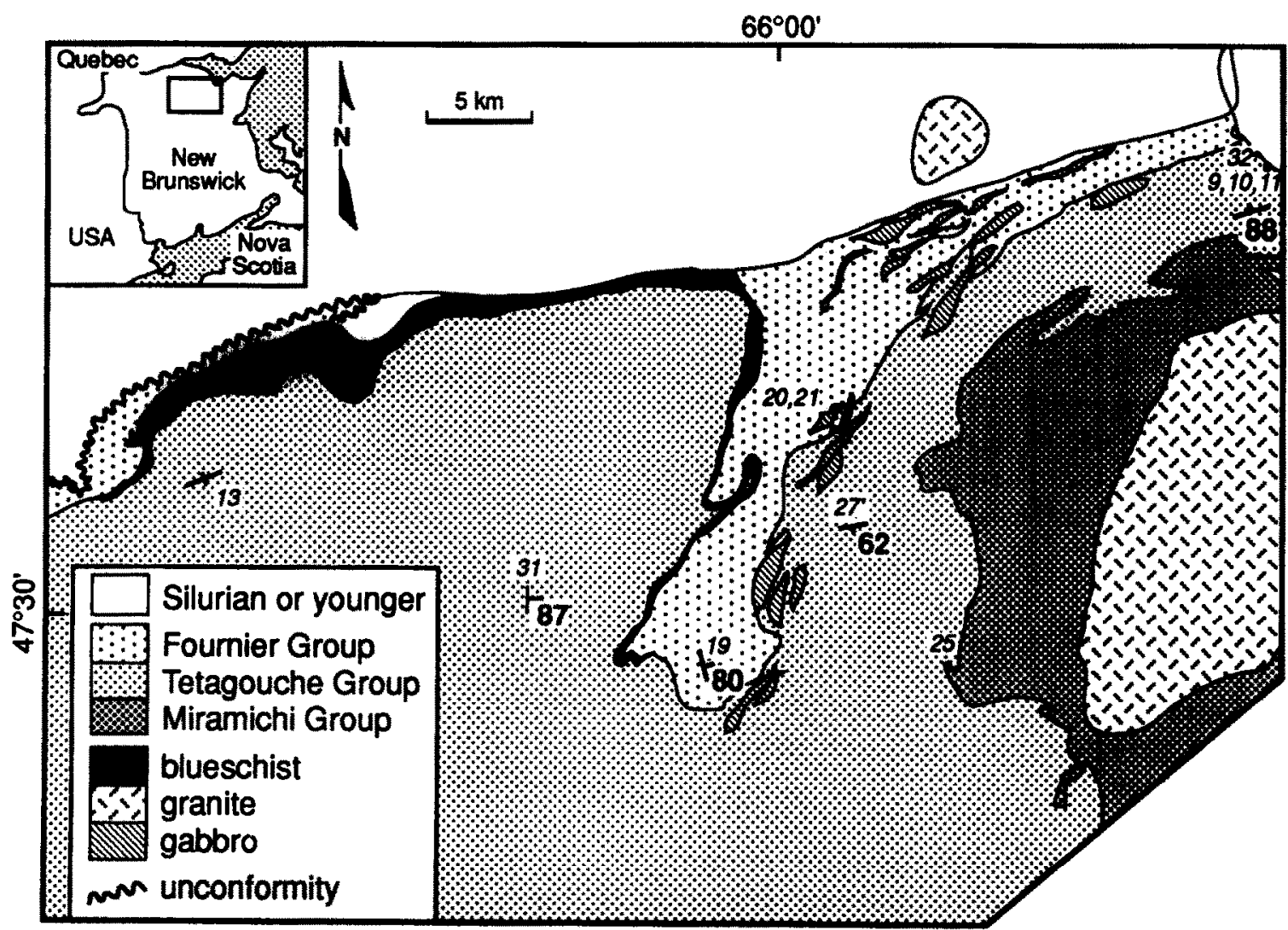

Fig. 2. Site location map and generalized geology. Numbers in italics represent the sites used to calculate the Tetagouche Group paleomagnetic mean direction and are shown with their bedding orientation. Sites 28 and 29 fall just to the north of the map area, but were not used in the final analysis. Geology simplified from van Staal et al. (1990). 
consists of submarine sedimentary and bimodal mafic and felsic volcanic rocks (Skinner, 1974; Whitehead and Goodfellow, 1978; van Staal, 1987). Geochemical analyses (Whitehead and Goodfellow, 1978; Paktunc, 1990; Fyffe et al., 1990; van Staal et al., 1991) define the mafic volcanics as intraplate alkalic and tholeiitic basalts that were erupted on a crust transitional between continental and oceanic. Metamorphic temperatures in these rocks do not exceed middle greenschist facies conditions. The association of marine sedimentary rocks (turbidites, red and black shales, some carbonates) with these endmember types of volcanic rocks, implies a continental rifting event with subsequent marine sediment deposition (van Staal, 1987). U-Pb zircon ages of 472-457 Ma (van Staal et al., 1990) date this rifting suite as Middle Ordovician.

The Fournier Group is an ophiolite complex (Rast and Stringer, 1980; Fyffe, 1987) that is overlain by turbidites with associated intrusives yielding $\mathrm{U}-\mathrm{Pb}$ ages ranging from 464 to $459 \mathrm{Ma}$ (Spray et al., 1990; van Staal et al., 1990). Early lithologic correlations (e.g., Pajari et al., 1977) equated the upper Tetagouche Group with the lower Fournier Group, and van Staal (1987) points out that similarities in conodonts and graptolites between the groups also support this correlation. The two groups are mainly distinguished by their chemistry and spatial separation relative to a blueschist belt (van Staal et al., 1991). The Fournier Group is characterized by back-arc basin geochemistry (Fyffe et al., 1990). These relationships between the Fournier and Tetagouche groups indicate that they were never widely separated.

\section{Deformation history}

Work by Helmstaedt (1971), Skinner (1974), and more recently by van Staal and coworkers (e.g., van Staal, 1987; van Staal et al., 1990) revealed a complex deformation history for northern New Brunswick. Van Staal (1987) recognized six generations of folding that have affected the Tetagouche Group. F1a and F1b are grouped together into D1 and represent a major episode of regional deformation that began in the Late
Ordovician and may have continued into the Early Silurian (van der Pluijm and van Staal, 1988); D1 is interpreted by van Staal (1987) to be the result of underthrusting and is characterized by isoclinal, recumbent structures that are highly localized in the area. F2 folding during the Siluro-Devonian steepened the pre-existing D1 structures. F3 produced large-scale, regional structures such as the Tetagouche antiform and the Nine Mile synform by means of ductile transcurrent faulting. Younger generations of folding (F4-F6) are represented by smaller-scale features (box folds, chevron folds, kinks).

\section{Paleomagnetic and rock magnetic data}

\section{Sampling techniques}

Standard $2.5-\mathrm{cm}$ paleomagnetic core samples or oriented hand samples were collected from thirteen sites in pillow basalts across the field area. Most outcrops in the area are unsuitable for paleomagnetic study because bedding control is absent or poor. One location, site 19 , was initially sampled prior to the re-definition of the regional geology by van Staal (1987) and is now considered to be located in the Fournier Group. However, the age and tectonic setting of the Fournier rocks are closely linked to those of the Tetagouche samples of this study (van Staal et al., 1990); therefore, this site has been included in the results. Approximately 150 samples were collected either from hand specimens or as cores obtained with a portable, gasoline-powered drill and oriented with a magnetic compass and clinometer. Based upon the magnetic intensities of the samples, it is unlikely that local magnetic effects caused erroneous in-situ orientation measurements.

\section{Laboratory techniques}

All samples were stored and treated in a shielded room at the Paleomagnetic Laboratory of the University of Michigan. Paleomagnetic measurements were made on either a Schonstedt SSM-1A spinner magnetometer or a Supercon- 


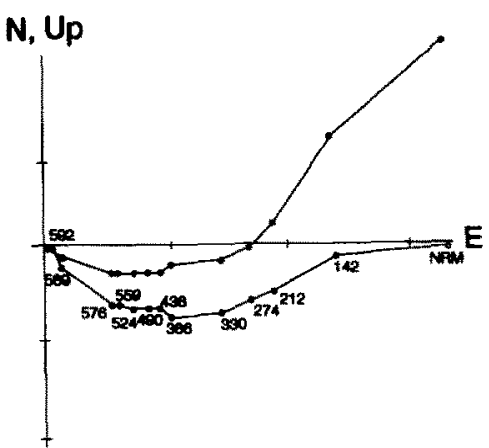

a. TG $10 \mathrm{~L}$ tic interval: $200 \mathrm{~mA} / \mathrm{m}$

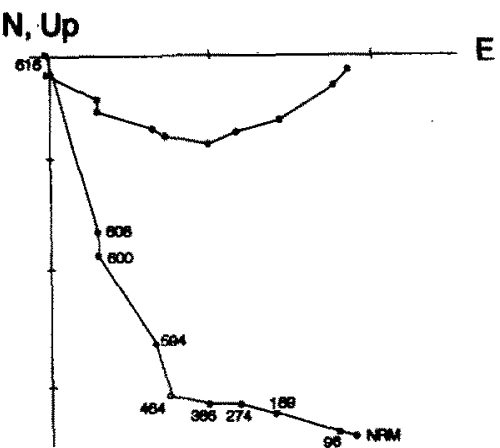

b. TG $19 \mathrm{~S}$ tic interval: $2 \mathrm{~mA} / \mathrm{m}$

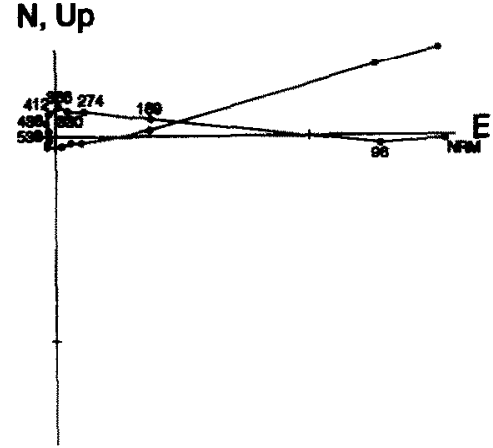

c. TG $31 \mathrm{~B}$ tic interval: $.5 \mathrm{~mA} / \mathrm{m}$

Fig. 3. Representative orthogonal vector diagrams: (a) sample from site TG 10; (b) sample from site TG 19; (c) sample from site TG 31 ; numbers associated with each point are thermal demagnetization steps $\left({ }^{\circ} \mathrm{C}\right)$. Dots represent horizontal component of magnetization direction; circles represent vertical component of magnetization direction; distance of points from origin represent intensities $(\mathrm{mA} / \mathrm{m})$. Samples in (a) and (b) display downward (reversed polarity) directions and that in (c) reveals an upward (normal polarity) direction.

ducting Technology (ScT) cryogenic magnetometer depending upon the magnetic intensity of each sample. The intensities of the natural remanent magnetizations (NRMs) of the samples ranged from $10^{-4} \mathrm{~A} / \mathrm{m}$ to $10 \mathrm{~A} / \mathrm{m}$. A preliminary suite of samples was treated with both stepwise-thermal and alternating-field (AF) demagnetization techniques to delineate the components of the NRM. The AF demagnetization method did not successfully separate the magnetization components, and the remaining samples were therefore treated thermally.

Following thermal treatment, the demagnetization results were plotted on orthogonal vector diagrams (Zijderveld, 1967) for visual inspection. Sample magnetic directions were ascertained using principal component analysis (Kirschvink, 1980). For samples that displayed curvilinear demagnetization trajectories, great-circle analysis (Halls, 1976) was applied. Of the thirteen sites available for this study, seven could be used to determine the ancient characteristic direction; the samples from the remaining six sites were excluded for reasons discussed below.

Tilt-corrections applied to the seven sites were ascertained from bedding orientations of adjacent sediments and/or pillow tops. The large variation in bedding orientation for these seven sites facilitates the application of a regional fold test, as will be presented in a later section.
Results

Figure 3 illustrates representative orthogonal vector demagnetization diagrams (Zijderveld, 1967). Overprints have been observed, which in some cases coincide with the present-day Earth's magnetic field for this location $\left(D=346^{\circ}, I=\right.$ $+72^{\circ}$ at $47^{\circ} \mathrm{N}, 294^{\circ} \mathrm{E}$ ), but most appear random. These low-temperature components were typically removed by $350^{\circ} \mathrm{C}$. Almost all samples completely unblocked by temperatures of approximately $585^{\circ} \mathrm{C}$, the Curie temperature of magnetite, suggesting that the remanence is carried by magnetite. Isothermal remanent magnetization (IRM) studies, showing saturation by $0.3-0.4 \mathrm{~T}$, further support magnetite as the main magnetic carrier of remanence (Tarling, 1983; Fig. 4). Reflected and transmitted light microscopy reveals the presence of hydrothermal alteration (expected for submarine volcanic rocks, e.g., zeolite-filling of vesicles, chlorite replacement of mafic minerals); however, hematite replacement of magnetite grains and evidence for secondary magnetite (e.g., small grains on vesicle walls) have not been observed.

At higher temperatures, samples from six sites $\left(9,10,11,13,19,27^{\prime}\right)$ revealed downward (presumably reversed) polarity directions (e.g., Figs. $3 a, 3 b)$, and normal polarity directions were found at one site (31, Fig. 3c). For sites in which sam- 

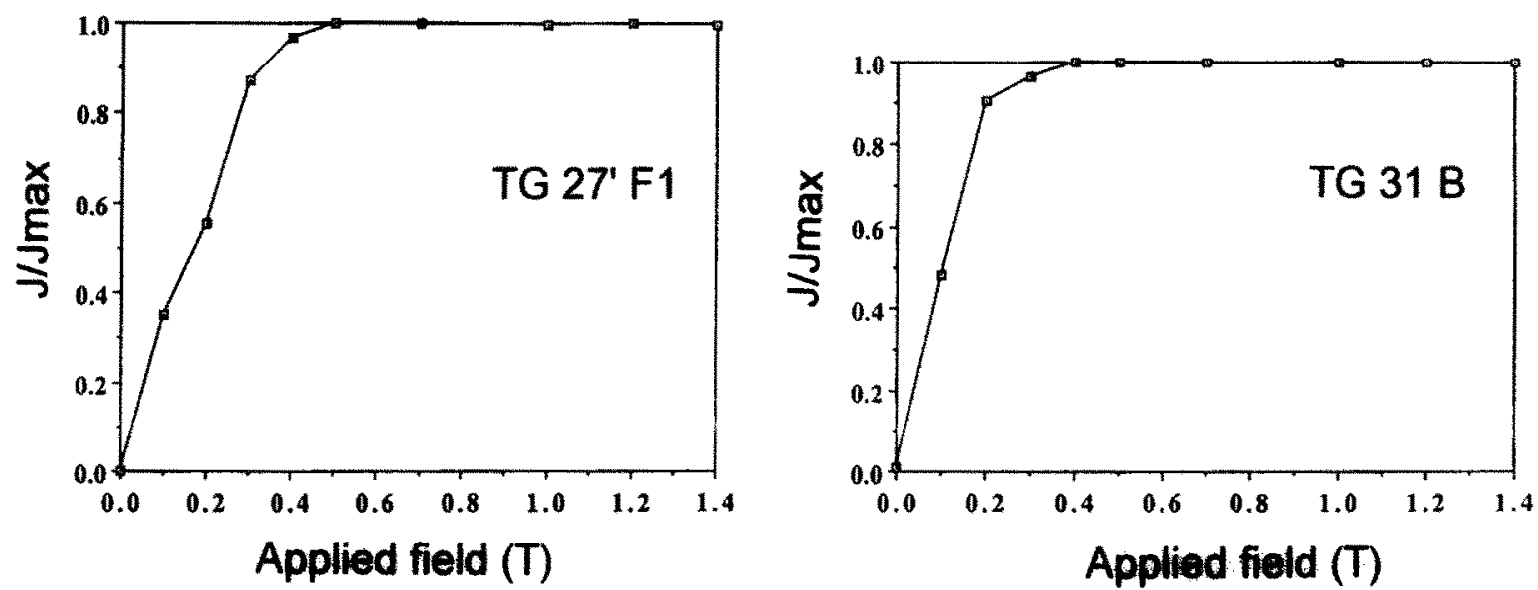

Fig. 4. Isothermal remanent magnetization (IRM) acquisition curves for samples from sites TG $27^{\prime}$ and TG 31. Shape of curves and saturation by $0.3-0.4 \mathrm{~T}$ suggest magnetite as the main carrier of remanence.

TABLE 1

Summary of site mean paleomagnetic directions

\begin{tabular}{|c|c|c|c|c|c|c|}
\hline Site & $S / D$ & $N_{d} / N_{d} / N$ & $\begin{array}{l}D / I \\
\mathbf{I}-\mathbf{S}\end{array}$ & $\begin{array}{l}D / I \\
\mathrm{~T} \cdot \mathrm{C}\end{array}$ & $\begin{array}{l}k \\
\mathrm{~T}-\mathrm{C}\end{array}$ & $\begin{array}{l}\alpha_{95} \\
\text { T-C }\end{array}$ \\
\hline \multicolumn{7}{|c|}{ Sites used to calculate Miramichi terrane mean } \\
\hline TG 9 & $248 / 90 \mathrm{~N}$ & $13 / 0 / 18$ & $146 /-01$ & $075 / 79$ & 14 & 11 \\
\hline TG 10 & $258 / 88 \mathrm{~N}$ & $11 / 5 / 22$ & $141 /-05$ & $097 / 62$ & 13 & 12 \\
\hline TG 11 & $248 / 90 \mathrm{~N}$ & $5 / 2 / 7$ & $151 /-05$ & $106 / 83$ & 10 & 23 \\
\hline TG 13 & $248 / 90 \mathrm{~N}$ & $7 / 2 / 13$ & $119 / 13$ & $049 / 48$ & 40 & 8 \\
\hline TG 19 & $348 / 80 \mathrm{E}$ & $13 / 0 / 17$ & $248 / 24$ & $107 / 74$ & 48 & 6 \\
\hline TG $27^{*}$ & $083 / 62 S$ & $4 / 5 / 17$ & $013 / 00$ & $031 / 56$ & 33 & 20 \\
\hline TG 31 & $003 / 87 \mathrm{E}$ & $3 / 3 / 8$ & $116 /-14$ & $211 /-64$ & 11 & 18 \\
\hline \multicolumn{7}{|c|}{ Sites that displayed unstable demagnetization behavior } \\
\hline TG 20 & $228 / 85 \mathrm{~N}$ & $0 / 0 / 9$ & - & - & - & - \\
\hline TG 21 & $228 / 85 \mathrm{~N}$ & $0 / 0 / 6$ & - & - & - & - \\
\hline TG 28 & $028 / 85 \mathrm{E}$ & $0 / 0 / 4$ & - & - & - & - \\
\hline TG 29 & $028 / 85 \mathrm{E}$ & $0 / 0 / 6$ & - & - & - & - \\
\hline \multicolumn{7}{|c|}{ Sites otherwise rejected (explained in text) } \\
\hline TG 25 & $208 / 82 W$ & $7 / 0 / 12$ & $166 / 80$ & $290 / 14$ & 13 & 16 \\
\hline TG 32 & $250 / 90 \mathrm{~N}$ & $7 / 2 / 10$ & $137 /-23$ & $116 / 58$ & 107 & 5 \\
\hline \multicolumn{7}{|c|}{ Statistical parameters from the calculation of the mean pole } \\
\hline & & & I-S & T-C & & \\
\hline Sample: & & & $73 / 7$ & $73 / 7$ & & \\
\hline Fisheria & of site means & & $140 /-6$ & $060 / 69$ & & \\
\hline$k$ & & & 5 & 22 & & \\
\hline$\alpha_{95}$ & & & 32 & 13 & & \\
\hline Paleom & ole & & & $52 \mathrm{~N}, 352 \mathrm{E}$ & & \\
\hline
\end{tabular}

Notes: $k$ and $\alpha_{95}$ are statistical parameters. $S / D=$ strike and dip; $D / I=$ declination and inclination. $I-S=$ in situ; T-C tilt corrected. $N_{\mathrm{d}}=$ number of samples that give stable endpoint directions; $N_{\mathrm{g}}=$ number of samples that give great-circle trajectories; $N=$ total number of samples demagnetized. 
ples displayed both stable endpoint and greatcircle trajectory demagnetization behavior, the method of Bailey and Halls (1984) was applied to calculate site mean directions. The seven sites displayed characteristic tilt-corrected directions with moderate to steep inclinations and some variability in the declinations.

All sample data, stable endpoint directions and poles to great-circles, are plotted in Figure 5, both in situ and tilt-corrected. Table 1 lists the

(a)
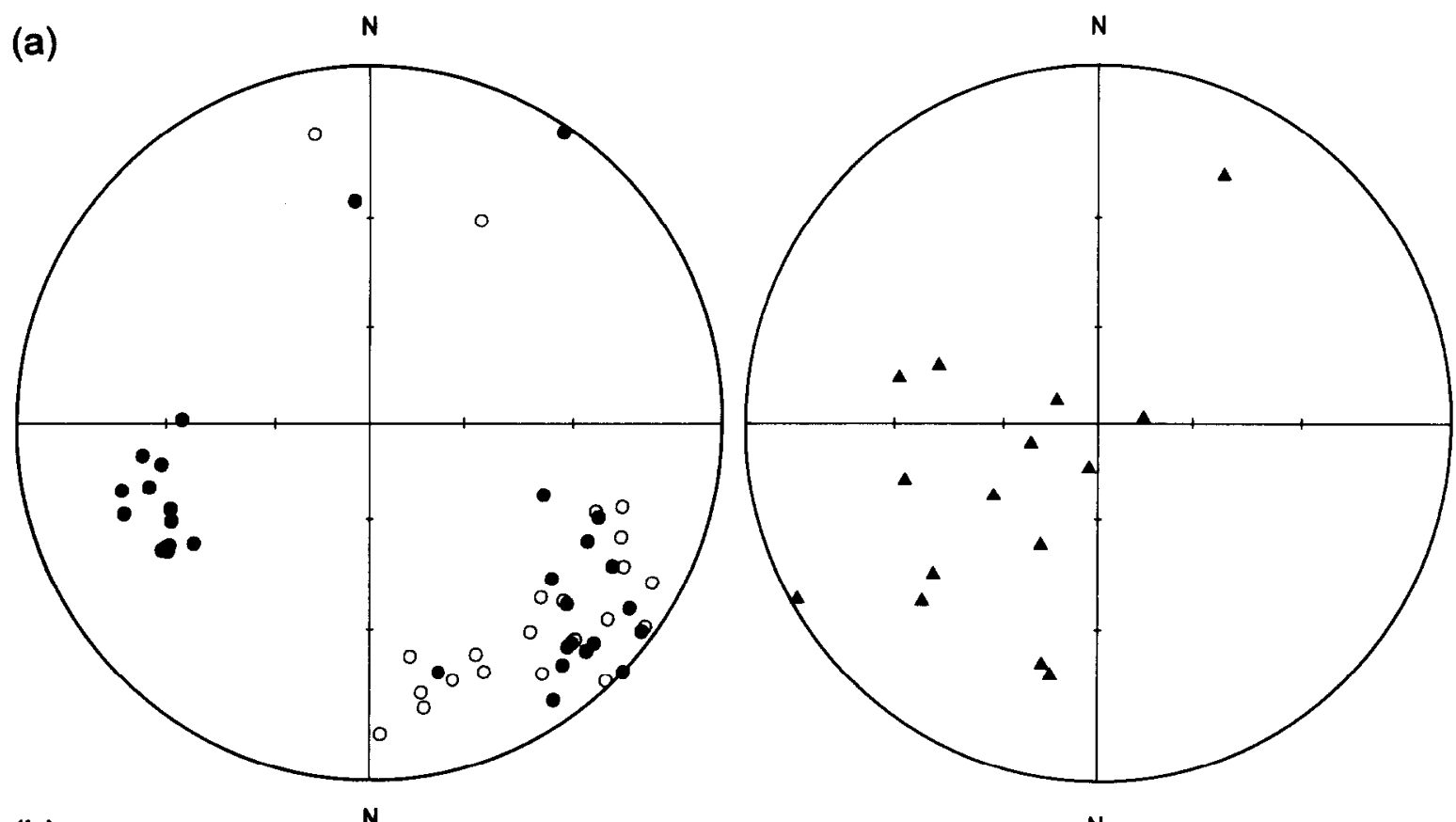

(b)
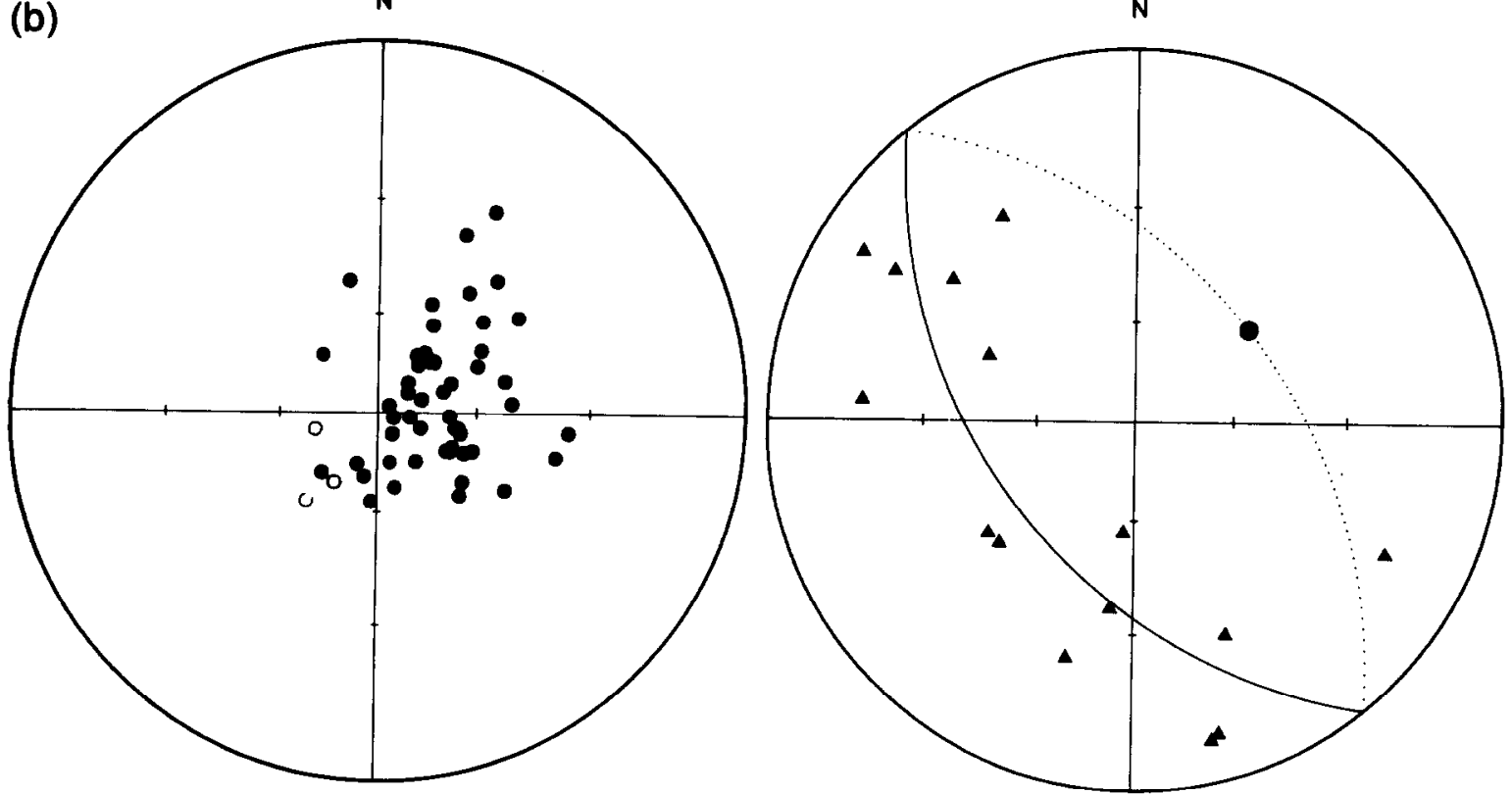

Fig. 5. High-temperature magnetization directions for samples from sites $9,10,11,13,19,27^{\prime}$ and 31 ; (a, c) in situ, (b, d) tilt-corrected; equal-angle projection. Dots represent reversed polarity (down) directions; circles are normal polarity (up) directions; triangles are poles to great-circle trajectories (lower hemisphere only); large dot on tilt-corrected great-circle plot represents pole to best-fit great circle through data (solid/dashed line in lower/upper hemisphere). In-situ directions vary widely, but upon tilt-correction, clustering of data increases. 
site means and the associated statistical parameters. The seven site means are plotted in Figure 6 , in both in-situ and tilt-corrected coordinates. The clustering of the directions for both sample and site means improves dramatically upon tilt correction as is shown by the increase in the precision parameter $k$ and the decrease in the $\alpha_{45}$ angle (Table 1). The group mean, calculated from the site mean data, yields a direction of $D=060^{\circ}, I=+69^{\circ}\left(\alpha_{95}=13, k=22, N=7\right.$, tiltcorrected; Table 1). The paleopole calculated from this direction is $52^{\circ} \mathrm{N}, 352^{\circ} \mathrm{E}(\mathrm{dp}=19, \mathrm{dm}=$ 22 ), and corresponds to a paleolatitude of $53^{\circ}$ for the Miramichi Terrane.

\section{Rejected sites}

Sites containing samples that displayed unstable demagnetization behavior were rejected (sites 20, 21, 28, 29; Table 1). Samples from site 32 demagnetized stably and coherently, but based on the originally determined field attitude $(S / D=$
$093 / 61 S$ ), the magnetization direction was neither similar to those from neighboring sites, nor to any younger magnetization direction presently known for North America. The site is a small exposed hill (approximately $2-3 \mathrm{~m}$ high) composed of pillow basalts. The original tilt-correction, however, is likely to be inadequate (C.R. van Staal, pers. commun., 1993). If the tilt-correction associated with nearby sites $9-11 \quad(S / D=$ $250 / 90 \mathrm{~N}$ ) is applied to the samples of site 32 , the magnetization direction ( $D / I=116 / 58$; Table 1$)$ clusters with the other sites. Nevertheless, in view of this correction we prefer not to include site 32 although it further improves our result. Site 25 not only contained samples that demagnetized both stably and coherently, but had excellent bedding control $(S / D=208 / 82 \mathrm{NW}$; Table 1$)$. However, after demagnetization the calculated direction $(D / I: 166 /+80$, in situ; $290 / 14$, tiltcorrected) was not representative of either the majority of the sites or any younger North American magnetization directions. Therefore, this site was also excluded from the analysis.
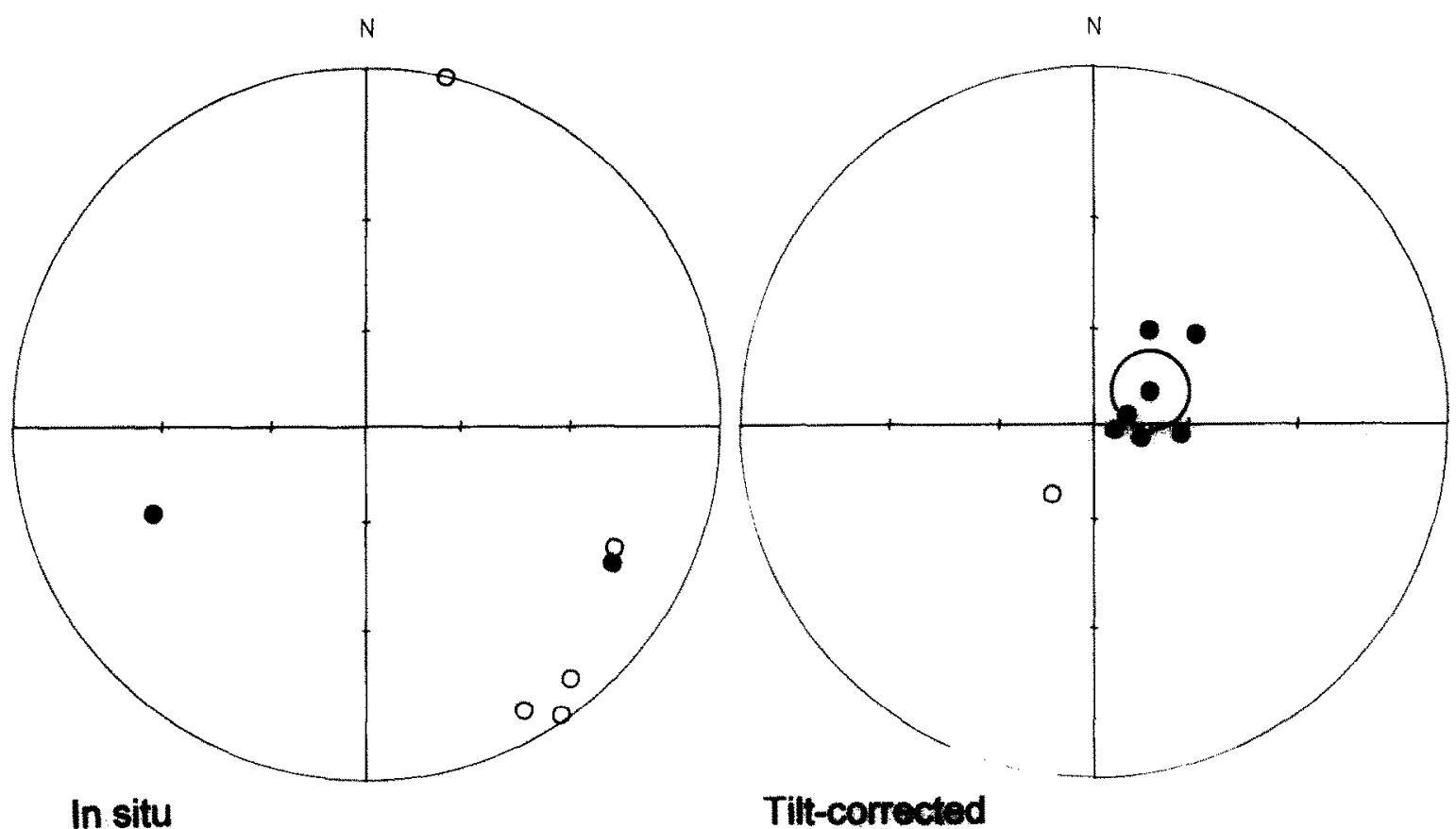

Tilt-corrected

Fig. 6. Site mean high-temperature magnetization directions for sites $9,10,11,13,19,27^{\prime}$ and 31 , in situ and tilt-corrected (see Table 1); equal-angle projection. The directions vary widely in situ, but converge upon tilt-correction. Dots (circles) represent lower (upper) hemisphere. Tetagouche Group tilt-corrected mean magnetization direction $\left(D=060^{\circ}, I=+69^{\circ}\right)$ is shown with confidence limit. 


\section{Anisotropy of magnetic susceptibility}

Samples from all sites were measured on a Sapphire Instruments SI-2 magnetic susceptibility and anisotropy meter. The magnetic susceptibility can be represented by a second-order tensor that is symmetric about a diagonal representing the maximum $(k 1)$, intermediate $(k 2)$, and minimum ( $k 3)$ susceptibilities. If there is a preferred orientation of ferromagnetic minerals, the anisotropy of magnetic susceptibility (AMS) should be significant. It has been shown (Uyeda et al., 1963; Hrouda, 1982) that with a high degree of anisotropy $(P>1.5$ or $50 \%$, where $P=k 1 / k 3)$, there can be a significant deflection of the direction of the acquired thermoremanent magnetization from the ambient Earth's magnetic field. AMS measurements were therefore performed in order to constrain the maximum possible deflection of the remanent magnetization vectors. Also, the magnetic susceptibility tensor has been related to strain (Graham, 1966; Hrouda, 1982; Borradaile, 1988), and it may be possible to determine the extent of strain qualitatively from the AMS although quantitative correlations are not straightforward. The AMS results from samples of the sites used to calculate the Tetagouche Group paleomagnetic direction are plotted in a Flinn-type diagram (Fig. 7) and show that less than $10 \%$ anisotropy $(P)$ is present in these samples. This low value indicates that there has been little deflection of the magnetic vector due to regional deformation. Furthermore, these low values qualitatively indicate that internal deformation did not significantly affect these samples.

\section{Fold test}

The variation in bedding across the area (see Fig. 2) allows for the application of a regional fold test to determine the timing of magnetization acquisition. In our subsequent analysis we will only consider the inclination after structural correction, which is not affected by rotated blocks. Stepwise unfolding of the seven site means at $10 \%$ increments shows a maximum value of $k$, a measure of clustering of the data, at $100 \%$ unfolding (Fig. 8). This result, accompanied by a

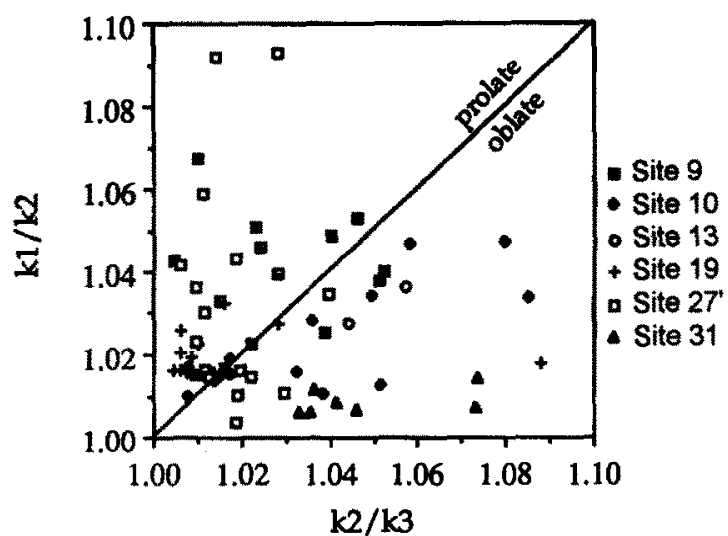

Fig. 7. Anisotropy of magnetic susceptibility (AMS) data for samples from the sites used to calculate the Tetagouche Group paleomagnetic pole. Some samples were demagnetized prior to the onset of the AMS study and are not included here. Axes $k 1 / k 2$ and $k 2 / k 3$ represent the magnetic lineation and magnetic foliation, respectively; $k 1 / k 2 / k 3$ are the maximum/intermediate/minimum susceptibilities. Line separates the prolate field from the oblate field (Flinn-type diagram).

decrease in $\alpha_{95}$ from 32 in situ to 13 tilt-corrected, gives a positive fold test (McElhinny, 1964; McFadden, 1990).

\section{Interpretation of paleomagnetic results}

Figure 9 plots the North American apparent polar wander path (APWP) using the mean

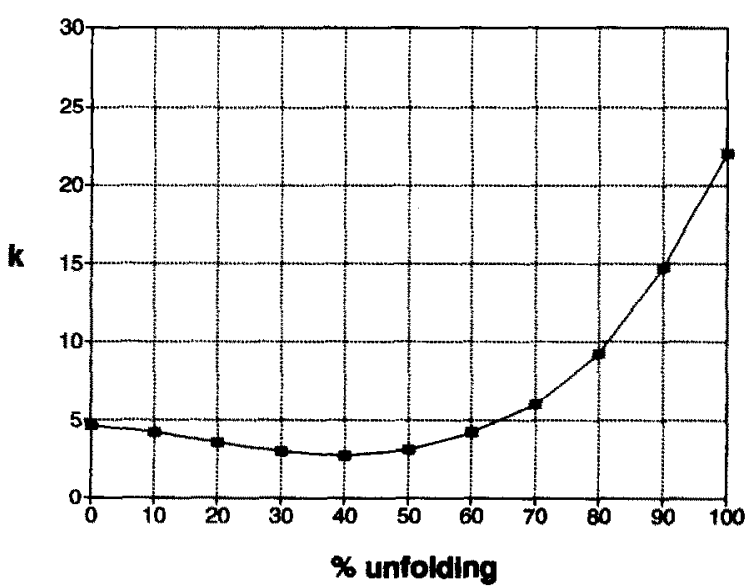

Fig. 8. Precision parameter $(k)$ vs. percent unfolding. The Tetagouche Group mean direction was unfolded at $10 \%$ increments yielding a maximum of $k$ at 100\% unfolding, which indicates that magnetization acquisition was prior to regional folding. 
Phanerozoic paleopoles of Van der Voo (1990) with a quality factor $Q>3$. The Tetagouche Group pole position obtained in this study, located at $52^{\circ} \mathrm{N}, 352^{\circ} \mathrm{E}$, is also plotted (square labeled TG). This pole falls significantly away from the North American APWP, not only for the Ordovician segment, but for the entire Phanerozoic. We interpret this dissimilarity of our paleopole to the North American APWP as evidence for the displaced nature of the Miramichi Terrane relative to North America. Alternatively, if the calculated magnetization direction is related to D1 (i.e., a pre-folding overprint), a possibility that is not excluded from the fold test, then we can conclude that this deformation took place significantly away from the Laurentian margin. In either case, the non-North American pole has similar implications for Ordovician paleogeographic reconstructions.
The paleolatitude of the Tetagouche Group is plotted along with those of the Avalonian tectonic elements (including southern Britain) in Figure 10; in this plot we have inferred that the magnetization is primary. The choice of a southerly (rather than northerly) paleolatitude is based on lower Paleozoic paleogeographic positioning of the Laurentian margin and Avalon, both of which were located in the Southern Hemisphere (Van der Voo, 1988). It is evident that in the Ordovician, the Tetagouche Group is latitudinally affiliated with Avalon and distinct from Laurentia which occupied a low latitudinal position throughout the Ordovician.

\section{Discussion and conclusions}

The Middle Ordovician Tetagouche Group volcanics yield a characteristic magnetization di-

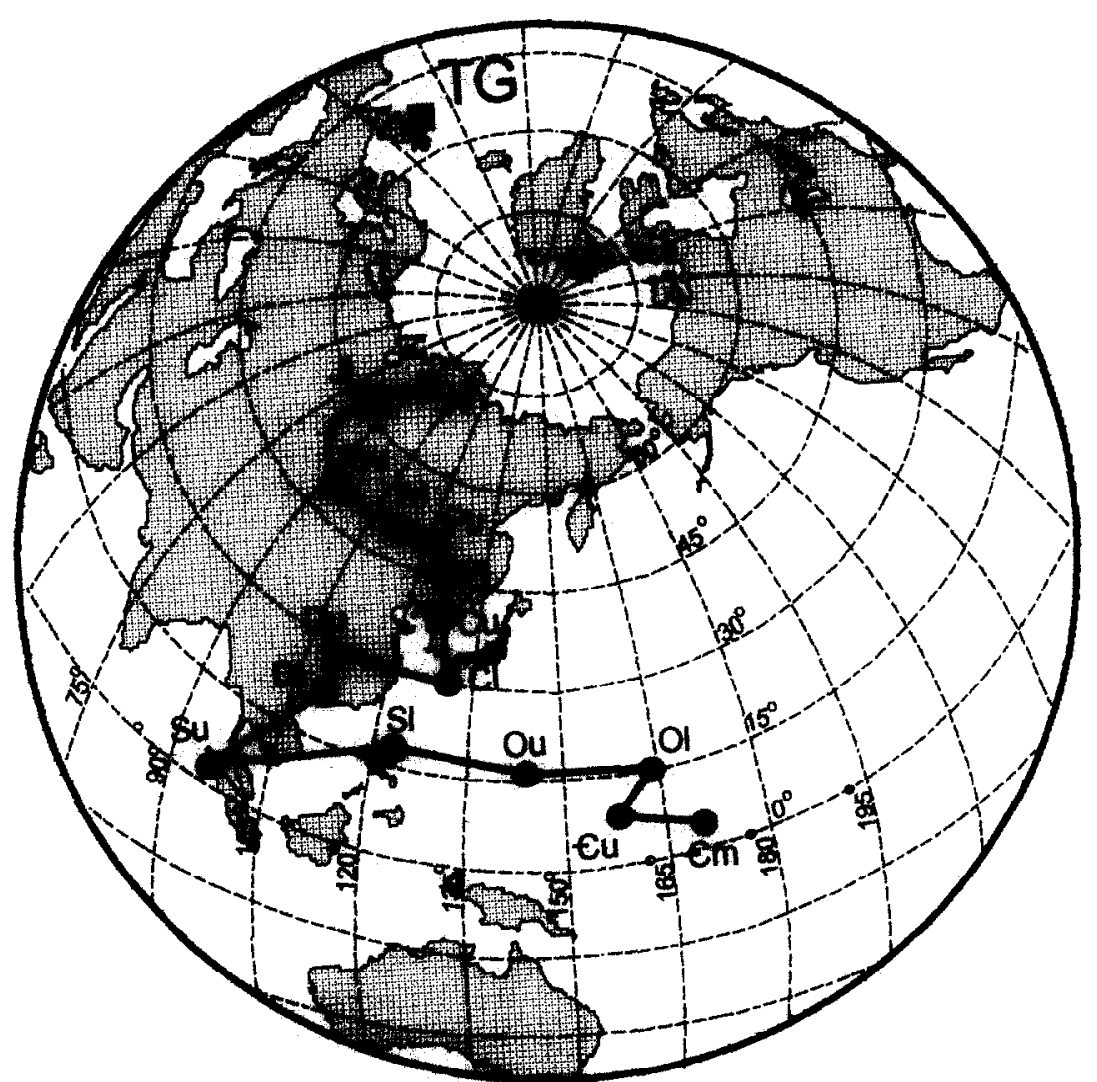

Fig. 9. Phanerozoic apparent polar wander path (APWP) for North America (after Van der Voo, 1990; $Q>3$ ) and the location of the Tetagouche Group paleopole (square labeled $T G$ ). 


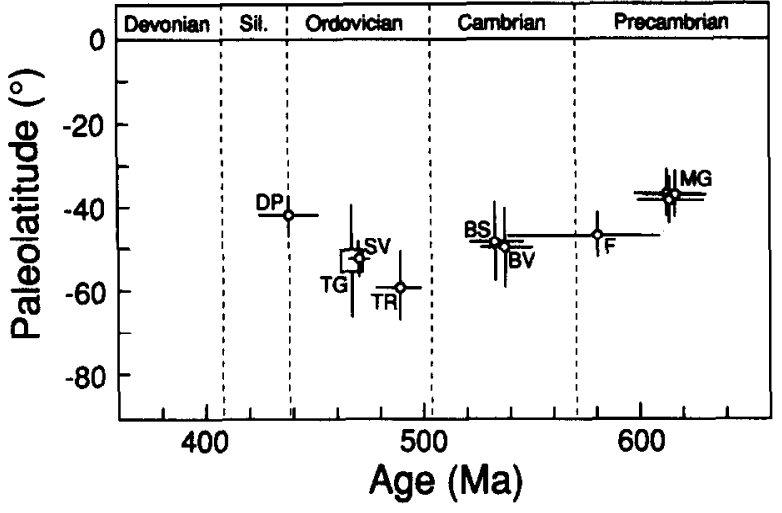

Fig. 10. Paleolatitudes of Avalonian elements as a function of time (see Table 2 for symbol explanation). In this plot we infer a Middle Ordovician age for the Tetagouche Group paleolatitude (large square labeled $T G$ ), but from our results a younger Ordovician age cannot be excluded. In either case the paleolatitude overlaps with that for Avalon.

rection of $D=060^{\circ}, I=+69^{\circ}\left(\alpha_{95}=13, N=7\right.$, $k=22$; tilt-corrected). Stepwise unfolding of the data showed the magnetization to have been acquired before the regional folding. The presence of a positive fold test and antipodal dual-polarity directions indicate that the ancient magnetization is Ordovician in age. The paleopole for the Tetagouche Group is calculated at $52^{\circ} \mathrm{N}, 352^{\circ} \mathrm{E}$ and falls distinctly away from the North Ameri- can APWP. In order to determine the tectonic history it is necessary to take into account the lithologic, spatial and temporal relationships of the Miramichi Terrane of northern New Brunswick, which indicate that the depositional sequence in Early Paleozoic time was: continental slope or rise sedimentation (Miramichi Group), followed by volcanism and dike emplacement during rifting of the edge of a continent (Tetagouche Group) and subsequent formation of oceanic crust (Fournier Group).

Comparison of the paleolatitude obtained for the Miramichi Terrane in this study $\left(53^{\circ} \mathrm{S}\right)$ to those of Early Paleozoic units of the Avalon Terrane shows the proximity of these two elements in Middle to Late Ordovician time. Because the Tetagouche Group was originally deposited in stratigraphic contact with the $\mathrm{Mi}$ ramichi Group, the latter was therefore also formed at the margin of Avalon. The progression of passive margin deposits, continental rifting and formation of oceanic crust suggests that the Fournier Group was also formed near the Avalonian margin of Iapetus. This is supported by one site in the Fournier Group that was analyzed for our study (site 19).

A pre-Late Ordovician scenario that reconciles the results of this study with local geologic and

TABLE 2

Paleolatitudes of Avalonian tectonic elements

\begin{tabular}{|c|c|c|c|c|c|c|}
\hline Formation name & Symbol & Age & Paleopole & PL & $\mathrm{dp}$ & Reference \\
\hline \multicolumn{7}{|l|}{ Nova Scotia } \\
\hline Fourchu Group & $\mathbf{F}$ & $610-540$ & $56 \mathrm{~N} 225 \mathrm{E}$ & 45 & 6 & Johnson and Van der Voo (1986) \\
\hline Bourinot Sediments & BS & $\sim 540$ & $33 \mathrm{~N} 354 \mathrm{E}$ & 47 & 11 & Johnson and Van der Voo (1985) \\
\hline Bourinot Volcanics & BV & $\sim 540$ & $21 \mathrm{~N} 340 \mathrm{E}$ & 49 & 11 & Johnson and Van der Voo (1985) \\
\hline Dunn Point Volcanics & DP & $437 \pm 15$ & $02 \mathrm{~N} 316 \mathrm{E}$ & 42 & 5 & Van der Voo and Johnson (1985) \\
\hline Dunn Point Volcanics & DP & $437 \pm 15$ & 02S $310 \mathrm{E}$ & 41 & 5 & Johnson and Van der Voo (1990) \\
\hline \multicolumn{7}{|l|}{ Newfoundland } \\
\hline $\begin{array}{l}\text { Marystown, Calmer } \\
\text { Marystown, }\end{array}$ & MG & $625-600$ & $32 \mathrm{~N} 231 \mathrm{E}$ & 36 & 6 & Irving and Strong (1985) \\
\hline Famine Back Cove & MG & $625-600$ & 01N 342E & 34 & 5 & Irving and Strong (1985) \\
\hline Marystown, Garnish & MG & $625-600$ & $05 \mathrm{~N} 329 \mathrm{E}$ & 34 & 7 & Irving and Strong (1985) \\
\hline \multicolumn{7}{|l|}{ Great Britain } \\
\hline Stapely Volcanics & SV & 473 & $26 \mathrm{~N} 036 \mathrm{E}$ & 51 & 7 & McCabe and Channel (1990) \\
\hline $\begin{array}{l}\text { Treffgarne lavas and } \\
\text { volcaniclastic sediments }\end{array}$ & TR & $490 \pm 10$ & $56 \mathrm{~N} 306 \mathrm{E}$ & 60 & 9 & Torsvik and Trench (1991) \\
\hline
\end{tabular}

Note: $\mathrm{PL}=$ paleolatitudes that are calculated for individual site locations; $\mathrm{dp}=$ confidence limit. 
Paleolatitude (ㅇ)

10

1

(a) Cambrian

?

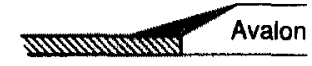

(b) Early Ordovician

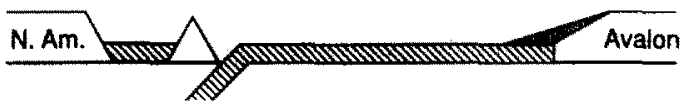

(c) Middle Ordovician

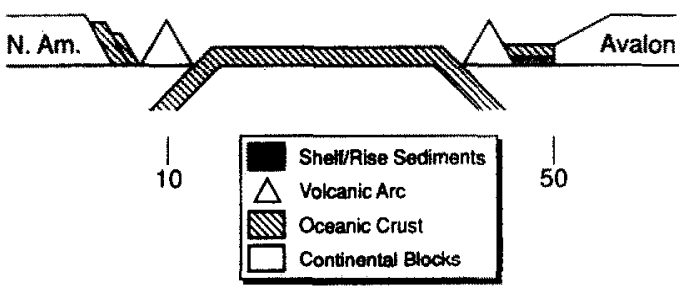

Fig. 11. Schematic diagram and tectonic model showing paleolatitude with time for the relevant tectonic elements. (a) Cambrian: deposition of the Miramichi sediments off the margin of Avalon. (b) Early Ordovician: continued deposition of Miramichi sediments while a back-arc basin opened at the Laurentian margin of lapetus. (c) Middle Ordovician: rifting and development of a back-arc basin proximal to Avalon.

geochemical data (e.g., Fyffe and Fricker, 1987; van Staal, 1987; Paktunc, 1990; David et al., 1991; van Staal and Fyffe, 1991; van Staal et al., 1991) and a recent paleogeographic model for the northern Appalachians (van der Pluijm et al., 1990, 1993) is depicted in Figure 11. Deposition of the Miramichi Group at the Avalonian passive margin began in Cambrian times (Fig. 11a) and continued into the Early Ordovician, while a back-arc basin formed at the Laurentian margin of Iapetus. The Tetagouche Group, overlying the Miramichi Group, represents continental rifting at the Avalonian margin and the Fournier Group the opening of a small back-arc basin that was floored by oceanic crust (Fig. 11c). We follow the geometry proposed in van Staal et al. (1991) for this subduction zone/arc/back-arc complex, but the details remain speculative at this time. The timing of rifting at the Avalonian margin coincides approximately with the closure of the backarc basin at the Laurentian margin. Continued Late Ordovician and Silurian northward subduction along the Laurentian margin of Iapetus resulted in final accretion of the Miramichi Terrane to the North American margin (not shown in Fig. $11)$.

\section{Acknowledgements}

This paper is based on the first author's M.Sc. thesis at the University of Michigan. We thank Rcx Johnson for help with ficld sampling and some preliminary demagnetization of samples, John Langton and Cees van Staal for generous aid during and after the 1990 field season in New Brunswick, and Joe Meert and Steve Potts for discussions and help with the laboratory aspects of this study. This paper benefited from reviews by Ken Buchan, Les Fyffe, Chad McCabe and an anonymous reviewer, and discussions with Cees van Staal. Research was supported by the National Science Foundation grants EAR 89-05811 and EAR 91-18021, a Sigma Xi Grant-in-Aid of Research and a Scott Turner Award from the Department of Geological Sciences at the University of Michigan.

\section{References}

Ayuso, R.A. and Bevier, M.L., 1991. Regional differences in $\mathrm{Pb}$ isotopic compositions of feldspars in plutonic rocks of the northern Appalachian mountains, U.S.A., and Canada: a geochemical method of terrane correlation. Tectonics, 10: $191-212$.

Bailey, R.C. and Halls, H.C., 1984. Estimate of confidence in paleomagnetic directions derived from mixed remagnetization circle and direct observational data. J. Geophysics, 54: 174-182.

Borradaile, G.J., 1988. Magnetic susceptibility, petrofabrics and strain. Tectonophysics, 156: 1-20.

David, J., Gariepy, C. and Philippe, S., 1991. Lower Paleozoic tholeiitic dykes from central New Brunswick: possible evidence for the early opening of an ensialic Taconian backarc basin. Can. J. Earth Sci., 28: 1444-1454.

Fyffe, L.R., 1977. Comparison of some tectonostratigraphic zones in the Appalachians of Newfoundland and New Brunswick: discussion. Can. J. Earth Sci., 14: 1468-1469.

Fyffe, L.R., 1987. Stratigraphy and tectonics of Miramichi and Elmtree terranes in the Bathurst area, northeastern New Brunswick. In: D.C. Roy (Editor), NE Section Geol. Soc. Am., Centennial Field Guide, 5: 389-393.

Fyffe, L.R. and Fricker, A., 1987. Tectonostratigraphic terrane analysis of New Brunswick. Marit. Sediments Atl. Geol., 23: 113-122.

Fyffe, L.R., Forbes, W.H. and Riva, J., 1983. Graptolites from the Benton area of west-central New Brunswick and their 
regional significance. Marit. Sediments Atl. Geol., 19: 117-125.

Fyffe, L.R., van Staal, C.R. and Winchester, J.A., 1990. Late Precambrian-Early Paleozoic volcanic regimes and associated massive sulphide deposits in the northeastern mainland Appalachians. Can. Inst. Min. Metall. Bull., 83: 70-78.

Graham, J.W., 1966. Significance of magnetic anisotropy in Appalachian sedimentary rocks. In: J.S. Steinhart and T.J. Smith (Edditors), The Earth Beneath the Continents. Am. Geophys. Union, Geophys. Monogr., 10: 627-648.

Halls, H.C., 1976. A least-squares method to find a remanence direction from converging remagnetization circles. Geophys. J.R. Astron. Soc., 45: 297-304.

Helmstaedt, H., 1971. Structural geology of the Portage Lakes area, Bathurst-Newcastle district, New Brunswick. Geol. Surv. Can., Pap. 70-28.

Hrouda, F., 1982. Magnetic anisotropy of rocks and its application in geology and geophysics. Geophys. Surv., 5: 37-82.

Irving, E. and Strong, D.F., 1985. Paleomagnetism of rocks from Burin Peninsula, Newfoundland; hypothesis of Late Paleozoic displacement of Acadia criticized. J. Geophys. Res., 90: 1949-1962.

Johnson, R.J.E. and Van der Voo, R., 1985. Middle Cambrian paleomagnetism of the Avalon terrane in Cape Breton Island, Nova Scotia. Tectonics, 4: 629-651.

Johnson, R.J.E. and Van der Voo, R, 1986. Paleomagnetism of the Late Precambrian Fourchu Group, Cape Breton Island, Nova Scotia. Can. J. Earth Sci., 23: 1673-1685.

Johnson, R.J.E. and Van der Voo, R., 1990. Pre-folding magnetization reconfirmed for the Late Ordovician-Early Silurian Dunn Point volcanics, Nova Scotia. Tectonophysics, 178: 193-205.

Johnson, R.J.E., van der Pluijm, B.A. and Van der Voo, R., 1991. Paleomagnetism of the Moreton's Harbour Group, northeastern Newfoundland Appalachians: evidence for an Early Ordovician island arc near the Laurentian margin of lapetus. J. Geophys. Res, 96: 11,689-11,701.

Kirschvink, J.L., 1980. The least-squares line and plane and the analysis of paleomagnetic data. Geophys. J.R. Astron. Soc., 62: 699-718.

Marillier, F., Keen, C.E., Stockmal, G.S., Quinlan, G., Williams, H., Colman-Sadd, S.P. and O'Brien, S.J., 1989. Crustal structure and surface zonation of the Canadian Appalachians: implications of deep seismic reflection data. Can. J. Earth Sci., 26: 305-321.

McCabe, C. and Channell, J.E.T., 1990. Paleomagnetic results from volcanic rocks of the Shelve Inlier, Wales: evidence for a wide Late Ordovician Iapetus Ocean in Britain. Earth Planet. Sci. Lett., 196: 458-468.

McElhinny, M.W., 1964. Statistical significance of the fold test in paleomagnetism. Geophys. J.R. Astron. Soc., 8: 338-340.

McFadden, P.L., 1990. The fold test revisited. Geophys. J. Int., 102: 323-331.

Neuman, R.B., 1984. Geology and paleobiology of islands in the Ordovician Iapetus Ocean: review and implications. Geol. Soc. Am. Bull., 95: 1188-1201.
Pajari, G.E., Rast, N. and Stringer, P., 1977. Paleozoic volcanicity along the Bathurst-Dalhousic geotraverse, New Brunswick and its relation to structure. In: W.R.A. Baragar, L.C. Coleman and J.M. Hall (Editors), Volcanic Regimes in Canada. Geol. Assoc. Can., Spec. Pap., 16: 111-124.

Paklunc, A.D., 1990. Geochemical constraints on the tectonic setting of the mafic rocks of the Bathurst Camp, Ap palachian Orogen. Can. J. Earth Sci., 27: 1182-1193.

Rast, N. and Stringer, P., 1974. Recent advances and the interpretation of geological structure of New Brunswick. Geosci. Can., 2: 15-25.

Rast, N. and Stringer, P., 1980. A geotraverse across a deformed Ordovician ophiolite and its Silurian cover, north ern New Brunswick, Canada. Tectonophysics, 69;221-245.

Rast, N., Kennedy, MJ. and Blackwood, R.F., 1976. Comparison of some tectonostratigraphic zones in the Appalachians of Newfoundland and New Brunswick. Can. J. Earth Sci., 13: 868-875.

Ruitenberg, A.A., Fyffe, L.R., McCutcheon, S.R., St. Peter, C.J., Irrinki, R.R and Venugopal, D.V., 1977. Evolution of pre-Carboniferous tectonostratigraphic zones in the New Brunswick Appalachians. Geosci. Can., 4: 171-181.

Skinner, R., 1974. Geology of the Tetagouche Lakes, Bathurst and Nepisiguit Falls map-areas, New Brunswick with emphasis on the Tetagouche Group. Geol. Surv. Can., Mem., 371.

Spray, J.G., Flagler, P.A. and Dunning, G.R., 1990. Crystallization and emplacement chronology of the Fournier oceanic fragment, Canadian Appalachians. Nature, 344: 232-235.

Stockmal, G.S., Colman-Sadd, S.P., Keen, C.E., Marillier, F., O'Brien, S.J. and Quinlan, G.M.,, 1990. Deep seismic structure and plate tectonic evolution of the Canadian Appalachians. Tectonics, 9: 45-62.

Tarling, D.H., 1983. Paleomagnetism: Principles and Applications in Geology, Geophysics and Archeology. Chapman and Hall, London.

Torsvik, T.H. and Trench, A., 1991. The Ordovician history of the lapetus Ocean in Britain: new paleomagnetic constraints. J. Geol. Soc., London, 148: 423-425.

Uyeda, S., Fuller, M.D., Belshe, J.C. and Girdler, R.W., 1963. Anisotropy of magnetic susceptibility of rocks and minerals. J. Geophys. Res., 68: 279-291.

van der Pluijm, B.A. and van Staal, C.R., 1988. Characteristics and evolution of the Central Mobile Belt, Canadian Appalachians. J. Geol., 96: 535-547.

van der Pluijm, B.A., Johnson, R.J.E. and Van der Voo, R., 1990. Early Paleozoic paleogeography and accretionary history of the Newfoundland Appalachians. Geology, 18: 898-901.

van der Pluijm, B.A., Johnson, R.J.E, and Van der Voo, R., 1993. Paleogeography, accretionary history, and tectonic scenario: a working hypothesis for the Ordovician and Silurian evolution of the northern Appalachians. In: D.C. Roy and J.W. Skehan (Editors), The Acadian Orogeny: 
Recent Studies in New England, Maritime Canada, and the Autochthonous Foreland. Geol. Soc. Am., Spec. Pap., 275: $27-40$.

Van der Voo, R., 1988. Paleozoic paleogeography of North America, Gondwana, and intervening displaced terranes: comparisons of paleomagnetism with paleoclimatology and biogeographical patterns. Geol. Soc. Am. Bull., 100: 311324.

Van der Voo, R., 1989. Paleomagnetism of North America: the craton, its margins, and the Appalachian Belt. In: L.C. Pakiser and W.D. Mooney (Editors), Geophysical Framework of the Continental United States. Geol. Soc. Am., Mem., 172: 447-469.

Van der Voo, R, 1990. Phanerozoic paleomagnetic poles from Europe and North America and comparisons with continental reconstructions. Rev. Geophys., 28: 167-206.

Van der Voo, R. and Johnsun, R.J.E., 1985. Paleomagnetism of the Dunn Point Formation (Nova Scotia); high paleolatitudes for the Avalon terrane in the Late Ordovician. Geophys. Res. Lett., 12: 337-340.

Van der Voo, R., Johnson, R.J.E., van der Pluijm, B.A. and Krutson, L.C., 1991. Paleogeography of some vestiges of Iapetus: paleomagnetism of the Ordovician Robert's Arm, Summerford, and Chanceport Groups, central Newfoundland. Geol. Soc. Am. Bull., 103: 1564-1575.

van Staal. C.R., 1987. Tectonic setting of the Tetagouche Group in northern New Brunswick: implications for plate tectonic models of the northern Appalachians. Can. J. Earth Sci., 24: 1329-1351.

van Staal, C.R. and Fyffe, L.R., 1991. Dunnage and Gander zones, New Brunswick: Canadian Appalachian region. New Brunswick Department of Natural Resources and Energy, Mineral Resources. Geoscience Report 91-2 (preprint of Chapter 3 in Geology of the Appalachian/Caledonian Orogen in Canada and Greenland. Geol. Soc. Am., The Geology of North America, F-1). van Staal, C.R., Ravenhurst, C.E., Winchester, J.A., Roddick, J.C. and Langton, J.P., 1990. A pust-Taconic blueschist suture in northern New Brunswick, Canada. Geology, 18: 1073-1077.

van Staal, C.R., Winchester, J.A. and Bedard, J.H., 1991. Geochemical variations in Middle Ordovician volcanic rocks of the northern Miramichi Highlands and their tectonic significance. Can. J. Earth Sci., 28: 1031-1049.

Wellensiek, M.R., van der Pluijm, B.A., Van der Voo, R. and Johnson, R.J.E., 1990. Tectonic history of the Lunksoos composite terrane in the Maine Appalachians. Tectonics, 9: 719-734.

Whitehead, R.E.S. and Goodfellow, W.D., 1978. Geochemistry of volcanic rocks from the Tetagouche Group, Bathurst, New Brunswick, Canada. Can. J. Earth Sci., 15: 207-219.

Willians, H., 1964. The Appalachians in northeastern Newfoundland -a two-sided symmetrical system. Am. J. Sci., 262: 1137-1158.

Williams, H., 1979. Appalachian Orogen in Canada. Can. J. Earth Sci., 16: 792-807.

Williams, H. and Hatcher, R.D., Jr., 1983. Appalachian suspect terranes. In: R.D. Hatcher, Jr., H. Williams and I. Zietz (Editors), Contributions to the Tectonics and Geophysics of Mountain Chains. Geol. Soc. Am., Mem., 158: $33-53$.

Willians, H., Colman-Sadd, S.P. and Swinden, H.S., 1988. Tectonic-stratigraphic subdivisions of central Newfoundland. In; Current Research, Part B. Geol. Surv. Can., Pap. 88-1B: $91-98$.

Zijderveld, J.D.A., 1967. AC demagnetization of rocks: analysis of results. In: D.W. Collinson, K.M. Creer and S.K. Runcorn (Editors), Methods in Paleomagnetism. Elsevier, Amsterdam, pp. 254-286. 